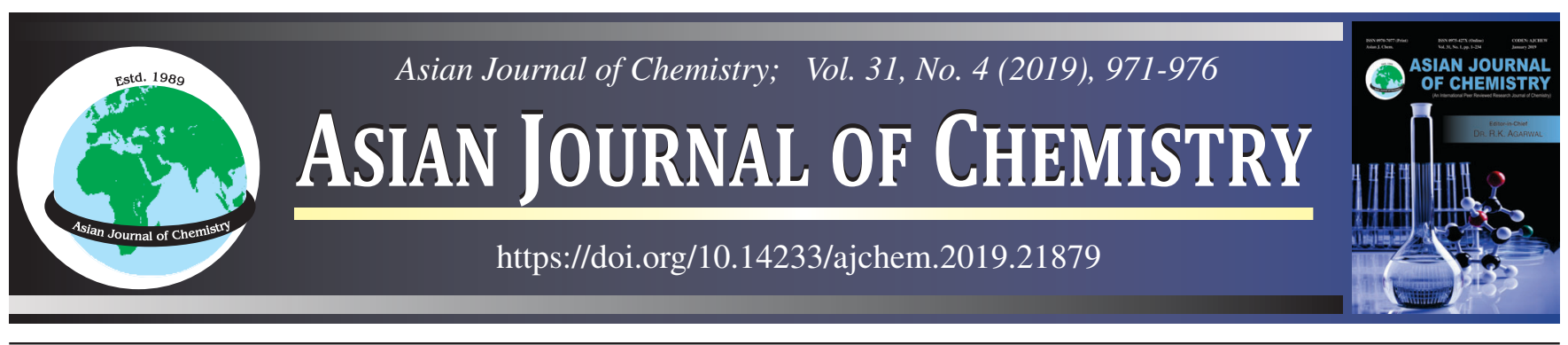

\title{
Intramolecular Excited-State Proton Transfer in Biologically Active Flavones: A Combined Experimental and Theoretical Study
}

\author{
Sanjay Kumar, L. Saya, H.C. TAndon and Shikha Gulati*
}

Department of Chemistry, Sri Venkateswara College (University of Delhi), Delhi-110021, India

*Corresponding author: E-mail: shikha2gulati@gmail.com

Received: 17 December 2018;

Accepted: 28 January 2019;

Published online: 27 February 2019;

AJC-19314

\begin{abstract}
The absorption and fluorescence characteristics of two biologically active flavone derivatives 6-hydroxy-7,3', 4',5' -tetramethoxyflavone (6HTMF) and 7-hydroxy-6,3',4', 5' -tetramethoxyflavone (7HTMF) were studied as a function of acidity (pH/ $\left.\mathrm{H}_{0}\right)$ of the solution. Dissociation constants were determined for ground and first excited singlet states and the results were compared with those obtained from ForsterWeller calculations. The acidity constants for these two compounds (6HTMF and 7HTMF) obtained from fluorimetric titrations are in poor agreement with those obtained from Forster-Weller data but are in good agreement with ground state $\mathrm{pK}_{\mathrm{a}}$ values indicated the deactivation of excited state $\left(S_{1}\right)$ before the prototropic equilibrium is complete. The broad band emission of both the flavones in acidic aqueous solution suggests their use as tuneable dye lasers. 6-Hydroxy-7,3',4',5'-tetramethoxyflavone undergoes adiabatic photo-dissociation in the singlet excited state indicating the formation of an exciplex or a photo-tautomer. The stability of photo-tautomer was confirmed by calculated value of enthalpy of formation using AM1 method.
\end{abstract}

Keywords: Flavones, Dissociation constants, Prototropic equilibrium, AM1 method, Phototautomer.

\section{INTRODUCTION}

Flavones are well-known for their efficient biological use in medicinal industry as highly potential anticancer, antiinflammatory and antiallergic agents [1-5]. These properties are attributed to the structure of flavones which is based on their chemical behaviour. On going from ground state to excited state, there is a drastic change in these chemical properties. One such characteristic change on electronic excitation is in fluorescence intensity at different $\mathrm{pH}$ values. Solvent and $\mathrm{pH}$ dependent fluorescence spectroscopy has proved to be a valuable tool for studying primary photochemical processes, in particular, photo-dissociations and photo-protonations. The fluorescence based methods are also useful in understanding highly selective protein interactions and properties [6-8]. Since many transitions are accompanied by extensive reorganization of the molecular electron density, the acidity or basicity of such molecules may vary significantly in different electronic states. Therefore, the response of an otherwise neutral molecule to an incoming proton may strongly depend on the nature of the particular electronic state the acceptor molecule is in. Just as the absorbance of the acidic and basic forms of an acid-base system provides information concerning the extent of dissociation of the unexcited molecules, so does the fluorescence of the acidic and basic forms of excited molecules. Fluorescence, in comparison to absorbance, is thus a measure by which the change in acidity upon excitation can be detected. After Weber's study on fluorescence intensity variation with $\mathrm{pH}$ [9] and Forster's method to calculate $\mathrm{pK}_{\mathrm{a}}$ in excited state [10], Weller used the method of fluorimetric titrations [11]. Acidity constant values can, therefore, be calculated using Forster-Weller method by taking fluorescence intensity as a function of $\mathrm{pH}$ or Hammett's acidity scale $\left(\mathrm{H}_{0}\right)$. An interesting phenomenon is phototautomerism. Following charge transfer excitation, a molecule is protonated at one site and deprotonated at another site to form a tautomer. This often results in unusually large Stokes shift in the fluorescence band.

In continuation of our earlier work on the photophysical properties of certain novel flavone compounds [12-15], we have investigated the effect of $\mathrm{pH}$ on absorption and fluorescence spectra of the compounds 6-hydroxy-7,3', 4',5'-tetramethoxyflavone (6HTMF) and 7-hydroxy-6,3',4',5' -tetrame-

This is an open access journal, and articles are distributed under the terms of the Creative Commons Attribution-NonCommercial-ShareAlike 4.0 (CC BY-NC-SA 4.0) International License which allows readers to freely read, download, copy, distribute, print, search, or link to the full texts of its articles and to use them for any other lawful non-commercial purpose as long as the original source is duly acknowledged. 
<smiles>O=c1cc(-c2ccccc2)oc2ccccc12</smiles>

(a)<smiles>COc1cc2oc(-c3cc(OC)c(OC)c(OC)c3)cc(=O)c2cc1O</smiles>

(b)<smiles>COc1cc2oc(-c3cc(OC)c(OC)c(OC)c3)cc(=O)c2cc1O</smiles>

(c)

Fig. 1. Molecular structures of (a) flavone, (b) 6HTMF and (c) 7HTMF respectively

thoxyflavone (7HTMF) experimentally, as well as theoretically.

\section{EXPERIMENTAL}

The flavones (6HTMF and 7HTMF) were synthesized according to the standard reported methods [16-19] (Fig 1). Their structures and purity were confirmed on the basis of their known melting points and their ${ }^{1} \mathrm{H}$ NMR spectra. The absorption and fluorescence spectra were measured on a Kontron UV-930 spectrophotometer and Jasco FP-770 spectrofluorimeter respectively. All the solvents used, such as, benzene, ethyl acetate, acetonitrile, ethanol, methanol and triple distilled water were of spectroscopic grade. Analytical grade $\mathrm{H}_{2} \mathrm{SO}_{4}$ and $\mathrm{NaOH}$ were used to prepare acidic and basic solutions. A modified Hammet acidity scale [20] for solutions below pH 1.5 (using $\mathrm{H}_{2} \mathrm{SO}_{4}-\mathrm{H}_{2} \mathrm{O}$ mixture) was employed. Hammet's acidity function $\left(\mathrm{H}_{0}\right)$ serves to define as a measure of the tendency for the solution in question to transfer a proton to an uncharged or charged base molecule; increasingly negative values corresponding to higher acidity. Stock solutions were prepared in methanol $(10 \%)$ and diluted with different $\mathrm{pH} / \mathrm{H}_{0}$ solutions. Fluorimetric titrations were performed to calculate $\mathrm{pK}_{\mathrm{a}}$ values using the wavelengths of isosbestic points for excitation. These $\mathrm{pK}_{\mathrm{a}}$ values were used in calculation of $\mathrm{pK}_{\mathrm{a}}$ * values by Forster cycle method. Austin Model 1 (AM1) semi-empirical molecular orbital calculations were carried out to estimate the stability of the anionic, cationic and neutral species of both the systems and phototautomer of 6HTMF compound. These theoretical calculations have been carried out by using Hyperchem 7.52 version program [21].

\section{RESULTS AND DISCUSSION}

Absorption and fluorescence spectra of the flavones (6HTMF and $7 \mathrm{HTMF}$ ) have been studied at different $\mathrm{pH}$ ranging from 12.25 to $\mathrm{H}_{0}-7.80$ (Figs. 2-9, Tables 1-3). From the absorption spectra of 6HTMF and the absorption and fluorescence spectra of 7HTMF, three species are evident, namely the anion (A), the neutral molecule (N) and the cation (C) (Figs. $8 \& 9$ and Scheme-I). In contrast, four distinct fluorescence bands are observed in fluorescence spectra of 6HTMF on increasing the acidity of the solution from $\mathrm{pH} 12.25$ to $\mathrm{H}_{0}-6.50$. These bands have maxima at 594, 572, 532 and $562 \mathrm{~nm}$ and are assigned as anion (A), neutral molecule (N), cation (C) and a phototautomer (PT). The band at $562 \mathrm{~nm}$ is observed at $\mathrm{pH} 0.18$ in addition to a peak at $536 \mathrm{~nm}$ and has been ascribed to an

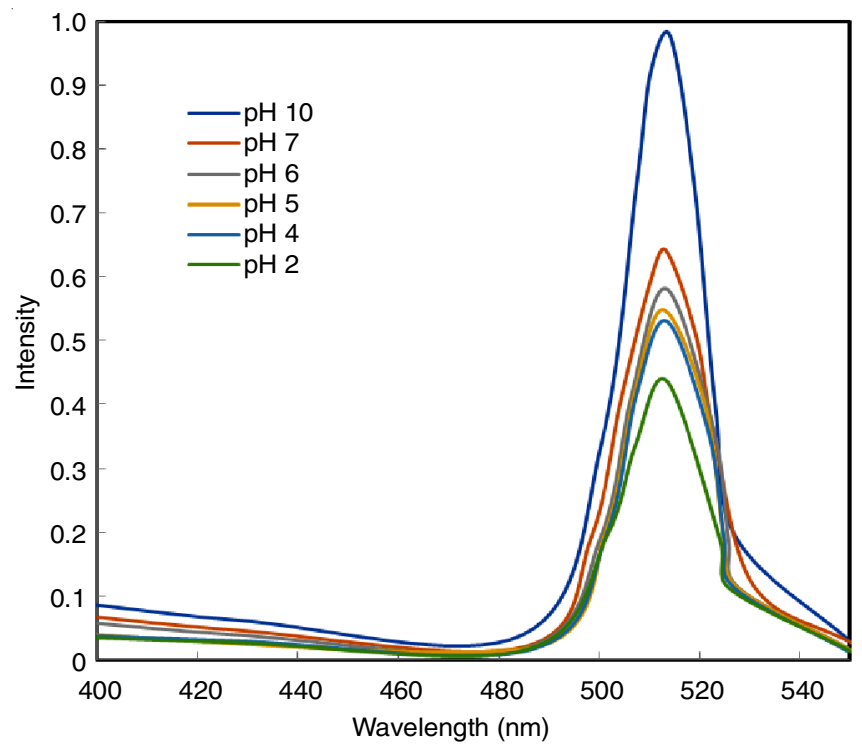

Fig. 2. Fluorescence spectra of 7HTMF at different $\mathrm{pH}$ values. Excited at isobestic wavelength $302 \mathrm{~nm}$

TABLE-1

SOLVENT AND ACIDITY DEPENDENT ABSORPTION, EXCITATION AND EMISSION MAXIMA $\left(\lambda_{\max } / \mathrm{nm}\right)$ OF FLAVONE

\begin{tabular}{cccccc}
\hline $\begin{array}{c}\text { Solvent } \\
\mathrm{pH} / \mathrm{H}_{0}\end{array}$ & $\lambda_{\max }^{\mathrm{abs}}$ & $\begin{array}{c}\text { Assigned } \\
\text { species }\end{array}$ & $\lambda_{\max }^{\mathrm{exc}}$ & $\lambda_{\max }^{\text {flu }}$ & $\begin{array}{c}\text { Assigned } \\
\text { species }\end{array}$ \\
\hline 7.00 & 304 & $\mathrm{~N}$ & - & - & - \\
0.00 & 306 & $\mathrm{C}$ & 330 & 405 & $\mathrm{C}$ \\
$\mathrm{H}_{0}-0.31$ & 310 & $\mathrm{C}$ & 330 & 405 & $\mathrm{C}$ \\
$\mathrm{H}_{0}-1.01$ & 324 & $\mathrm{C}$ & 328 & 405 & $\mathrm{C}$ \\
$\mathrm{H}_{0}-2.41$ & 345 & $\mathrm{C}$ & 330 & 405 & $\mathrm{C}$ \\
$\mathrm{H}_{0}-4.46$ & 348 & $\mathrm{C}$ & 350 & 405 & $\mathrm{C}$ \\
$\mathrm{H}_{0}-7.05$ & 350 & $\mathrm{C}$ & 355 & 405 & $\mathrm{C}$ \\
$\mathrm{H}_{0}-9.85$ & 355 & $\mathrm{C}$ & 355 & 405 & $\mathrm{C}$ \\
\hline
\end{tabular}

TABLE-2

SOLVENT AND ACIDITY DEPENDENT ABSORPTION, EXCITATION AND EMISSION MAXIMA $\left(\lambda_{\max } / \mathrm{nm}\right)$ OF 7-HYDROXY-7,3', 4', 5'-TETRAMETHOXYFLAVONE

\begin{tabular}{cccccc}
\hline $\begin{array}{c}\text { Solvent } \\
\mathrm{pH} / \mathrm{H}_{0}\end{array}$ & $\lambda_{\max }^{\text {abs }}$ & $\begin{array}{c}\text { Assigned } \\
\text { species }\end{array}$ & $\lambda_{\max }^{\text {exc }}$ & $\lambda_{\max }^{\text {flu }}$ & $\begin{array}{c}\text { Assigned } \\
\text { species }\end{array}$ \\
\hline 12.25 & 375 & $\mathrm{~A}$ & 283 & 572 & $\mathrm{~A}$ \\
10.14 & 376 & $\mathrm{~A}$ & 283 & 572 & $\mathrm{~A}$ \\
7.06 & 328 & $\mathrm{~N}$ & 277 & 560 & $\mathrm{~N}$ \\
5.00 & 328 & $\mathrm{~N}$ & 265 & 536 & $\mathrm{C}$ \\
0.18 & 329 & $\mathrm{~N}$ & 265 & 536 & $\mathrm{C}$ \\
$\mathrm{H}_{0}-0.31$ & 393 & $\mathrm{C}$ & 260 & 536 & $\mathrm{C}$ \\
$\mathrm{H}_{0}-1.72$ & 393 & $\mathrm{C}$ & 260 & 535 & $\mathrm{C}$ \\
$\mathrm{H}_{0}-4.46$ & 393 & $\mathrm{C}$ & 260 & 535 & $\mathrm{C}$ \\
\hline
\end{tabular}




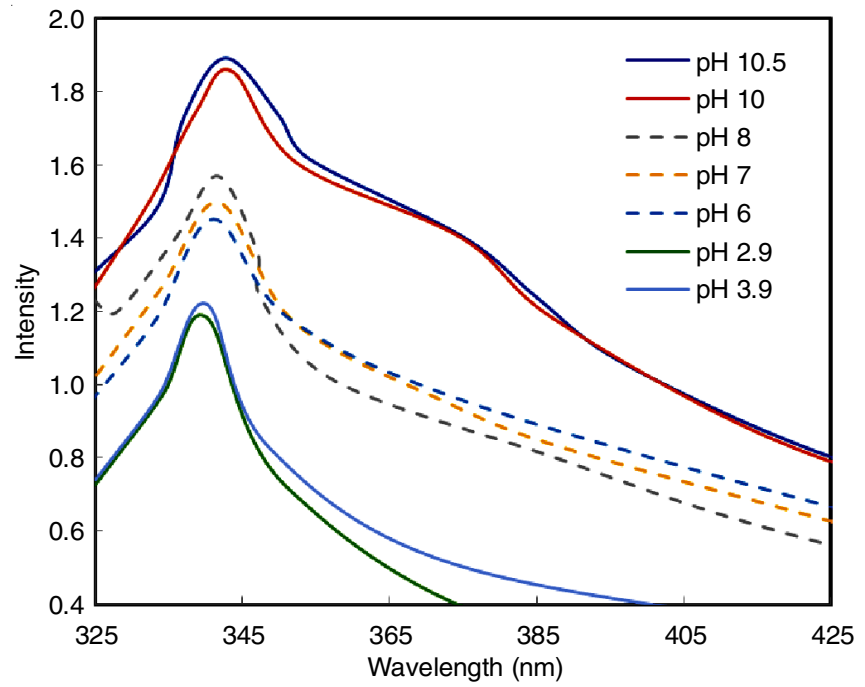

Fig. 3. Fluorescence spectra of $7 \mathrm{HTMF}$ at different $\mathrm{pH} / \mathrm{H}_{0}$

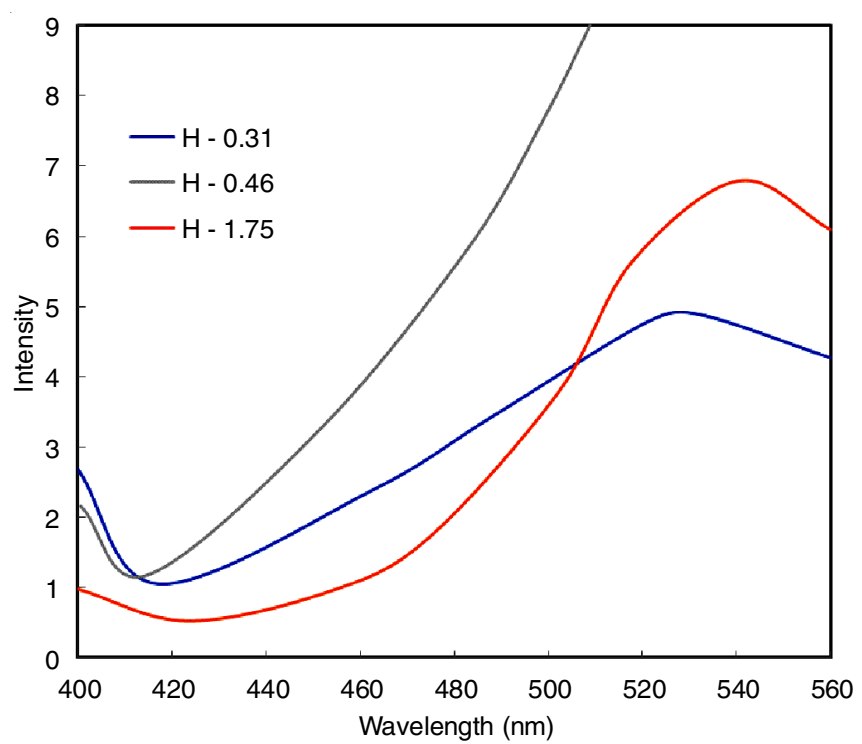

Fig. 4. Fluorescence spectra of $7 \mathrm{HTMF}$ at different $\mathrm{pH} / \mathrm{H}_{0}$

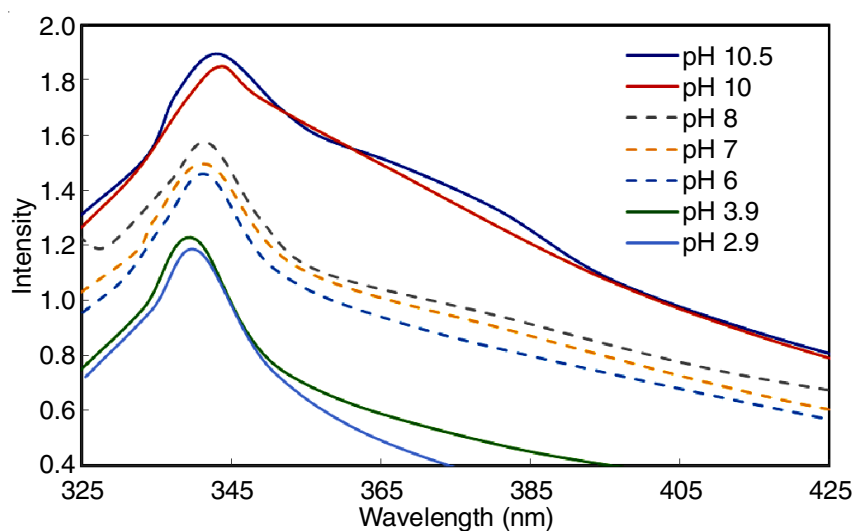

Fig. 5. Fluorescence spectra of $6 \mathrm{HTMF}$ at different $\mathrm{pH}$ values. Excited at isobestic wavelength $320 \mathrm{~nm}$

intramolecular phototautomer whose resonance structures are shown in the Scheme-II. This new species (phototautomer) should be formed in an adiabatic reaction during the life time of excited states.

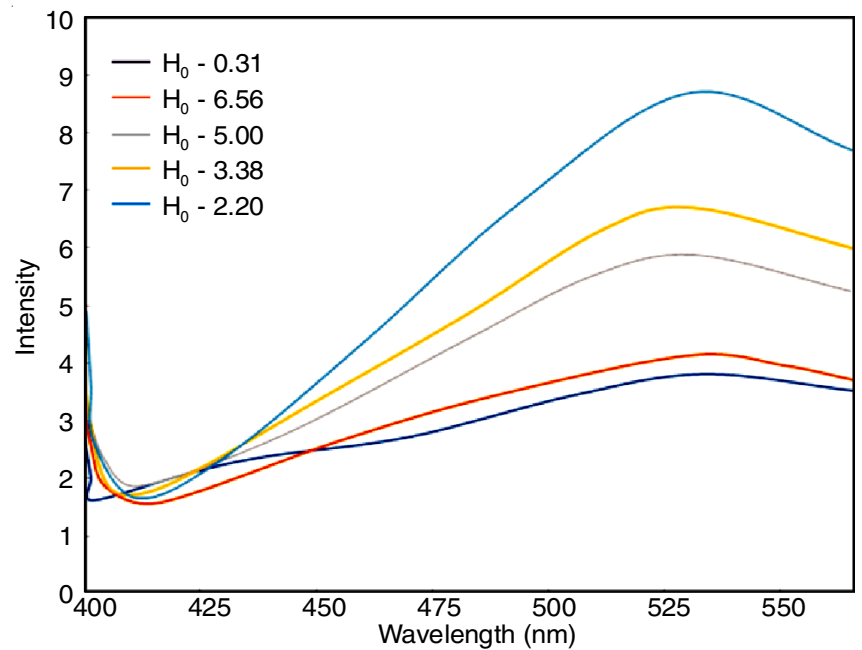

Fig. 6. Fluorescence spectra of $6 \mathrm{HTMF}$ at different $\mathrm{pH} / \mathrm{H}_{0}$

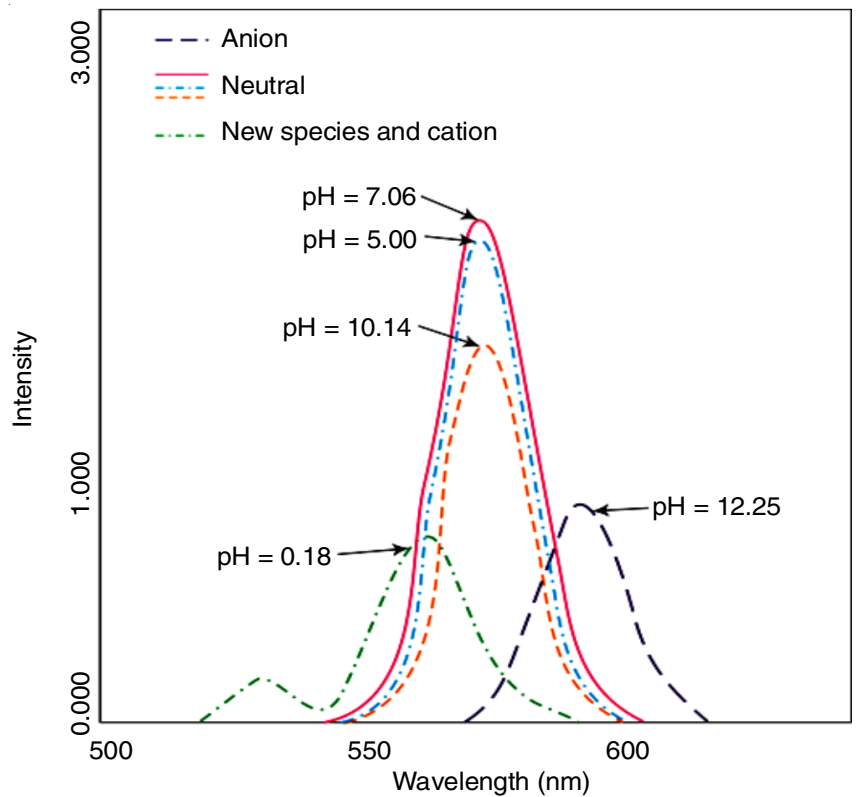

Fig. 7. Fluorescence spectra of $6 \mathrm{HTMF}$ at different $\mathrm{pH} / \mathrm{H}_{0}$

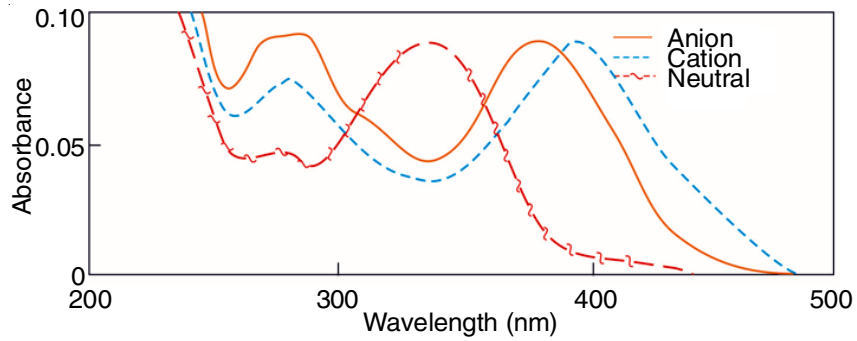

Fig. 8. Absorption spectra of $7 \mathrm{HTMF}$ at different $\mathrm{pH} / \mathrm{H}_{0}$

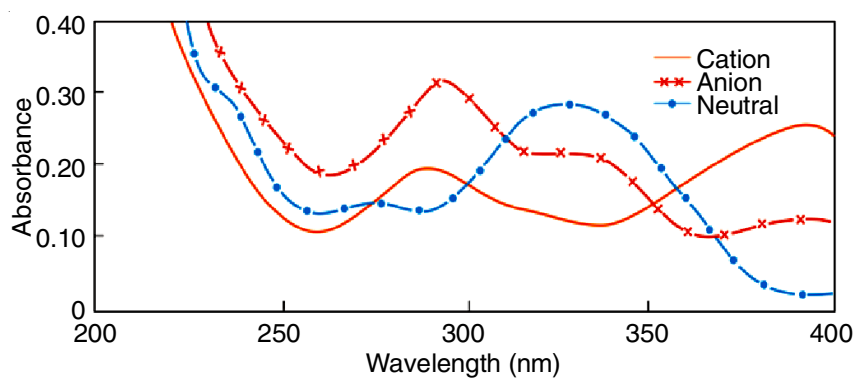

Fig. 9 Absorption spectra of $6 \mathrm{HTMF}$ at different $\mathrm{pH} / \mathrm{H}_{0}$ 
<smiles></smiles>

The existence of new species (phototautomer) in case of $6 \mathrm{HTMF}$ has been further confirmed by AM1 calculated values of enthalpy of formation and HOMO-LUMO energy gap (Tables 5 and 6) based on Frontier orbital theory [22]. The calculated values support the phototautomer to be more stable than cationic
TABLE-3

SOLVENT AND ACIDITY DEPENDENT ABSORPTION,

EXCITATION AND EMISSION MAXIMA $\left(\lambda_{\max } / \mathrm{nm}\right)$ OF 6-HYDROXY-7,3',4',5'-TETRAMETHOXYFLAVONE

\begin{tabular}{cccccc}
\hline $\begin{array}{c}\text { Solvent } \\
\mathrm{pH} / \mathrm{H}_{0}\end{array}$ & $\lambda_{\max }^{\text {abs }}$ & $\begin{array}{c}\text { Assigned } \\
\text { species }\end{array}$ & $\lambda_{\max }^{\text {exc }}$ & $\lambda_{\max }^{\text {flu }}$ & $\begin{array}{c}\text { Assigned } \\
\text { species }\end{array}$ \\
\hline 12.25 & 294 & $\mathrm{~A}$ & 294 & 594 & $\mathrm{~A}$ \\
10.14 & 294 & $\mathrm{~A}$ & 284 & 574 & $\mathrm{~N}$ \\
7.06 & 325 & $\mathrm{~N}$ & 284 & 574 & $\mathrm{~N}$ \\
5.00 & 326 & $\mathrm{~N}$ & 284 & 574 & $\mathrm{~N}$ \\
0.18 & 326 & $\mathrm{~N}$ & 278 & 562,532 & $\mathrm{PT}, \mathrm{C}$ \\
$\mathrm{H}_{0}-0.31$ & 393 & $\mathrm{C}$ & 260 & 532 & $\mathrm{C}$ \\
$\mathrm{H}_{0}-2.20$ & 393 & $\mathrm{C}$ & 260 & 532 & $\mathrm{C}$ \\
$\mathrm{H}_{0}-3.38$ & 393 & $\mathrm{C}$ & 260 & 531 & $\mathrm{C}$ \\
$\mathrm{H}_{0}-5.00$ & 393 & $\mathrm{C}$ & 260 & 531 & $\mathrm{C}$ \\
$\mathrm{H}_{0}-6.56$ & 393 & $\mathrm{C}$ & 260 & 532 & $\mathrm{C}$ \\
\hline
\end{tabular}

or anionic species. However, for 7HTMF, cation is found to be most stable due to lowest value of energy gap and highly negative enthalpy of formation values (Fig. 10).

Two excited state acidity constant $\left(\mathrm{pK}_{\mathrm{a}}{ }^{*}\right)$ values governing the A-N-C equilibria were estimated to be 3.4 and 3.37 for 7HTMF and 3.4 and 1.7 for 6 HTMF respectively, using the<smiles></smiles>

Phototautomer

Scheme-II: Resonating structures of 6HTMF 


\begin{tabular}{|c|c|c|c|c|c|c|c|}
\hline \multicolumn{8}{|c|}{$\begin{array}{c}\text { TABLE-4 } \\
\text { GROUND AND EXCITED STATE ACIDITY CONSTANTS (pK }{ }_{\mathrm{a}} \text { ) OF FLAVONES AND THEIR CONJUGATE ACIDS AT } 298 \mathrm{~K}\end{array}$} \\
\hline \multirow{2}{*}{ System } & \multirow{2}{*}{ Species } & \multirow{2}{*}{$\mathrm{pK}_{\mathrm{a}}$} & \multicolumn{3}{|c|}{ Foster-Weller calculations } & \multirow{2}{*}{$\Delta \mathrm{pK}_{\mathrm{a}}$} & \multirow{2}{*}{$\mathrm{pK}_{\mathrm{a}}^{*} / \mathrm{pK} \mathrm{a}_{\mathrm{a}}(\mathrm{FT})$} \\
\hline & & & $v_{\text {abs }}$ & $v_{\mathrm{fl}}$ & $v_{\mathrm{av}}$ & & \\
\hline \multirow{2}{*}{ Flavone } & $\mathrm{N}$ & - & 32895 & - & - & - & - \\
\hline & $\mathrm{C}$ & -1.33 & 28169 & - & - & 9.92 & $8.59 /-1.10$ \\
\hline \multirow{3}{*}{ 6HTMF } & $\mathrm{A}$ & - & 25641 & 16835 & 21238 & - & - \\
\hline & $\mathrm{N}$ & 7.70 & 30769 & 17422 & 24096 & 6.00 & $1.70 / 7.50$ \\
\hline & $\mathrm{C}$ & -0.85 & 25445 & 18793 & 22119 & 4.25 & $3.40 / \mathrm{f}$ \\
\hline \multirow{3}{*}{ 7HTMF } & $\mathrm{A}$ & - & 26667 & 17482 & 22075 & - & - \\
\hline & $\mathrm{N}$ & 7.80 & 30488 & 17857 & 24173 & 4.40 & $3.40 / 7.80$ \\
\hline & $\mathrm{C}$ & -1.05 & 25445 & 18692 & 22069 & 4.42 & $3.37 / \mathrm{f}$ \\
\hline
\end{tabular}

\begin{tabular}{|c|c|c|c|c|c|}
\hline \multicolumn{6}{|c|}{$\begin{array}{l}\text { TABLE-5 } \\
\text { THEORETICAL PROPERTIES OF 7-HYDROXY-7,3',4',5', -TETRAMETHOXYFLAVONE } \\
\text { AND ITS CONJUGATE ACIDS IN GASEOUS PHASE }\end{array}$} \\
\hline Species & $\lambda_{\max }(\mathrm{nm})$ & HOMO $(\mathrm{eV})$ & LUMO (eV) & $\Delta \mathrm{E}(\mathrm{eV})$ & $\begin{array}{c}\text { Enthalpy of formation } \\
\left(\mathrm{H}_{\mathrm{f}}\right)(\mathrm{kcal} / \mathrm{mol})\end{array}$ \\
\hline Anion & 284.4 & -9.237 & -1.035 & 8.202 & -156.1 \\
\hline Neutral & 283 & -9.066 & -0.836 & 8.131 & -184.2 \\
\hline Cation & 339.8 & -7.750 & -0.141 & 7.609 & -194.5 \\
\hline
\end{tabular}

\begin{tabular}{|c|c|c|c|c|c|}
\hline \multicolumn{6}{|c|}{$\begin{array}{c}\text { TABLE-6 } \\
\text { THEORETICAL PROPERTIES OF 6-HYDROXY-7,3',4',5' -TETRAMETHOXYFLAVONE } \\
\text { AND ITS CONJUGATE ACIDS IN GASEOUS PHASE }\end{array}$} \\
\hline Species & $\lambda_{\max }(\mathrm{nm})$ & $\mathrm{HOMO}(\mathrm{eV})$ & LUMO (eV) & $\Delta \mathrm{E}(\mathrm{eV})$ & $\begin{array}{c}\text { Enthalpy of formation } \\
\left(\mathrm{H}_{\mathrm{f}}\right)(\mathrm{kcal} / \mathrm{mol})\end{array}$ \\
\hline Anion & 243 & -9.074 & -0.928 & 8.146 & -156.8 \\
\hline Neutral & 285 & -8.861 & -0.958 & 7.902 & -180.6 \\
\hline Cation & 298 & -8.737 & -0.940 & 7.797 & -114.6 \\
\hline Phototautomer & 396 & -8.094 & -1.261 & 6.833 & -164.3 \\
\hline
\end{tabular}

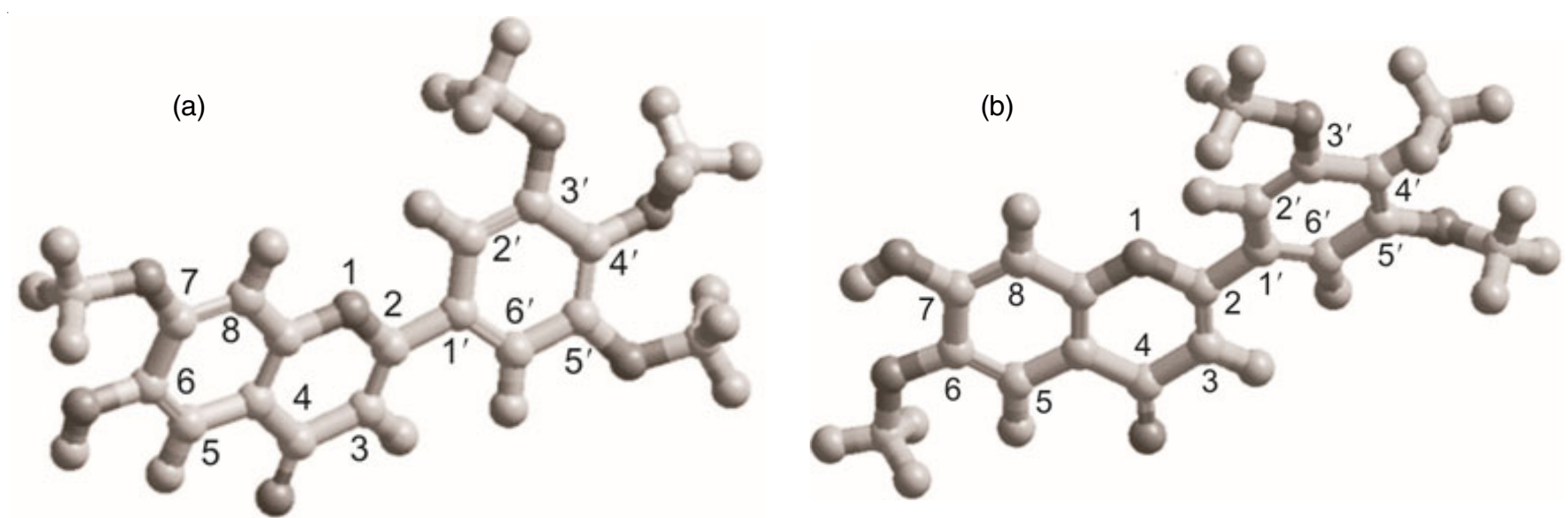

Fig. 10. Optimized geometry of neutral species of (a) 6HTMF and (b) 7HTMF

Forster cycle method. The $\mathrm{pK}_{\mathrm{a}}$ values obtained for both the systems by fluorescence titration (FT) method (7.7 and 7.5, Table-4) are in poor agreement with those obtained from Forster cycle method (3.4 and 3.4) but are in good agreement with ground state $\mathrm{pK}_{\mathrm{a}}$ values (7.8 and 7.7). This indicates deactivation of the excited state $\left(S_{1}\right)$ before the prototropic equilibrium is complete. The fluorimetric titration method is found to be less accurate because it is applicable only when there are two species in equilibrium. But in the flavones studied here, more than two species are in equilibrium with each other.

A broad band emission of these compounds in acidic aqueous solution suggests that they can be used as tunable dye lasers although the low values of fluorescence quantum yields of flavones [13] have adverse effect on their laser dye properties. Intensity of fluorescence maxima for both the flavones first increases on changing $\mathrm{pH}$ from 1 to 10 and decreases sharply from $\mathrm{pH} 10$ to 12.25 (Figs. 2, 5 and 7). This behaviour indicates small energy difference between the singlet and triplet excited states giving rise to more efficient intersystem crossing (Scheme-III).

\section{Conclusion}

The fluorimetric titration (FT) method for calculating $\mathrm{pK}_{\mathrm{a}}{ }^{*}$ values is found to be less accurate because it is applicable only 


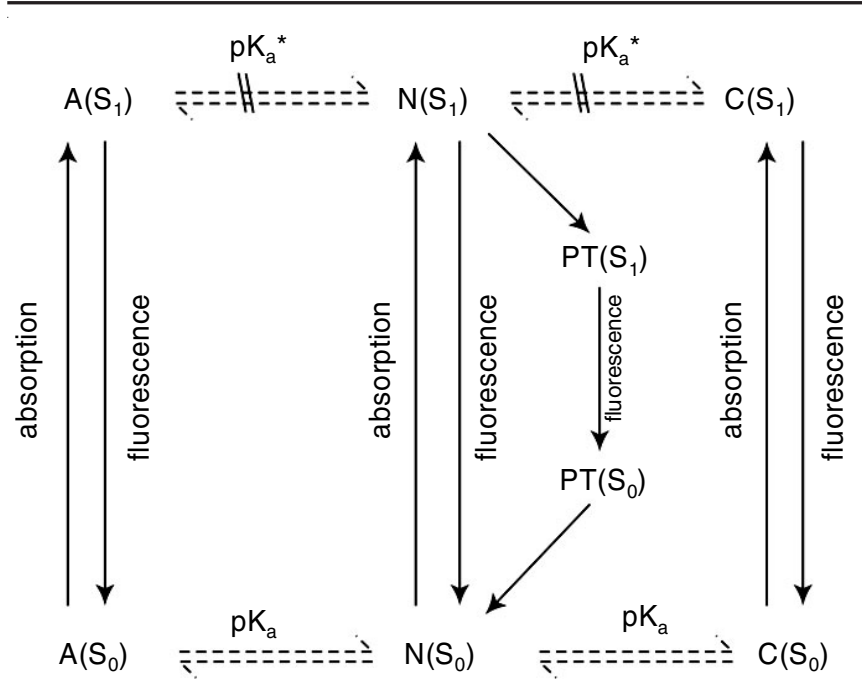

Scheme-III: Despite the predicted high basicity of $\mathrm{N}\left(\mathrm{S}_{1}\right)$, the excited state process $\mathrm{N}\left(\mathrm{S}_{0}\right) \rightarrow \mathrm{N}\left(\mathrm{S}_{1}\right) \rightarrow \mathrm{C}\left(\mathrm{S}_{1}\right) \rightarrow$ fluorescence plays no significant role in moderately acidic solutions. The path $\mathrm{N}\left(\mathrm{S}_{0}\right) \rightarrow \mathrm{N}\left(\mathrm{S}_{1}\right) \rightarrow \mathrm{PT}\left(\mathrm{S}_{1}\right) \rightarrow$ fluorescence is more favourable. The photodissociation of $\mathrm{N}\left(\mathrm{S}_{1}\right)$ to form fluorescent $\mathrm{A}\left(\mathrm{S}_{1}\right)$ predicted by Forster-Weller estimations occurs only to a very small extent

in cases of equilibrium containing two species. Analysis of absorption spectra for different $\mathrm{pH}$ indicates the existence of three species (i.e. anion, neutral and protonated form) of both the compounds whereas, fluorescence spectra analysis and enthalpy of formation values obtained from theoretical calculations confirm the existence of a new emitting species (phototautomer) for the 6HTMF molecule. This broadening of fluorescence spectra in both the compounds and formation of phototautomer on excitation (in case of 6HTMF) suggests their use as tuneable dye lasers. The decrease in intensity of fluorescence spectra of both the compounds in higher alkaline medium is probably due to more efficient intersystem crossing.

\section{CONFLICT OF INTEREST}

The authors declare that there is no conflict of interests regarding the publication of this article.

\section{REFERENCES}

1. M. Voicescu, S. Ionescu and F. Gatea, Spectrochim. Acta A Mol. Biomol. Spectrosc., 123, 303 (2014);

https://doi.org/10.1016/j.saa.2013.12.040.
2. K. Amrutha, P. Nanjan, S.K. Shaji, D. Sunilkumar, K. Subhalakshmi, L. Rajakrishna and A. Banerji, Bioorg. Med. Chem. Lett., 24, 4735 (2014); https://doi.org/10.1016/j.bmcl.2014.07.093.

3. Y.S. Huang and S.C. Ho, Food Chem., 119, 868 (2010); https://doi.org/10.1016/j.foodchem.2009.09.092.

4. B. Sengupta and P.K. Sengupta, Biochem. Biophys. Res. Commun., 299, 400 (2002); https://doi.org/10.1016/S0006-291X(02)02667-0.

5. J.A. Manthey, N. Guthrie and K. Grohmann, Curr. Med. Chem., 8, 135 (2001); https://doi.org/10.2174/0929867013373723.

6. O. Osman, A. Mahmoud, D. Atta, A. Okasha and M. Ibrahim, Der Pharma Chemica, 7, 377 (2015).

7. J. Fitter, A. Katranidis, T. Rosenkranz, D. Atta, R. Schlesinger and G. Büldt, Soft Matter, 7, 1254 (2011); https://doi.org/10.1039/C0SM00538J.

8. A. Katranidis, D. Atta, R. Schlesinger, T. Choli-Papadopoulou, K.H. Nierhaus, I. Gregor, M. Gerrits, G. Büldt and J. Fitter, Angew. Chem. Int. Ed., 48, 1758 (2009); https://doi.org/10.1002/anie.200806070.

9. K. Weber, Z. Phys. Chem. B, 15, 18 (1931).

10. Th. Forster, Z. Electrochem., 54, 42 (1950); https://doi.org/10.1002/bbpc.19500540111.

11. A. Weller, Z. Electrochem., 61, 956 (1957); https://doi.org/10.1002/bbpc.19570610818.

12. S. Kumar, V. Kapoor, R. Bansal and H.C. Tandon, J. Mol. Struct., 1156, 308 (2018); https://doi.org/10.1016/j.molstruc.2017.11.113.

13. S. Kumar, S.K. Jain, N. Sharma and R.C. Rastogi, Spectrochim. Acta A Mol. Biomol. Spectrosc., 57, 299 (2001); https://doi.org/10.1016/S1386-1425(00)00374-7.

14. S. Kumar, S.K. Jain and R.C. Rastogi, Spectrochim. Acta Part A: Mol. Biomol. Spectrosc., 57, 291 (2001); https://doi.org/10.1016/S1386-1425(00)00372-3.

15. S. Kumar, V.C. Rao and R.C. Rastogi, Spectrochim. Acta Part A: Mol. Biomol. Spectrosc., 57, 41 (2001); https://doi.org/10.1016/S1386-1425(00)00330-9.

16. T.S. Wheeler, Org. Synth. Coll., 4, 478 (1963).

17. J.H. Looker and W.W. Hanneman, J. Org. Chem., 22, 1237 (1957); http://dx.doi.org/10.1021/jo01361a030.

18. W. Baker, J. Chem. Soc., 1381 (1933); http://dx.doi.org/10.1039/JR9330001381.

19. H.S. Mahal and K. Venkatraman, Curr. Sci., 4, 214 (1933).

20. M.J. Jorgenson and D.R. Hartter, J. Am. Chem. Soc., 85, 878 (1963); https://doi.org/10.1021/ja00890a009.

21. Hyperchem 7.52, Hyper Cube Inc.: Florida (2003)

22. K. Fukui, T. Yonezawa and H. Shingu, J. Chem. Phys., 20, 722 (1952); https://doi.org/10.1063/1.1700523. 